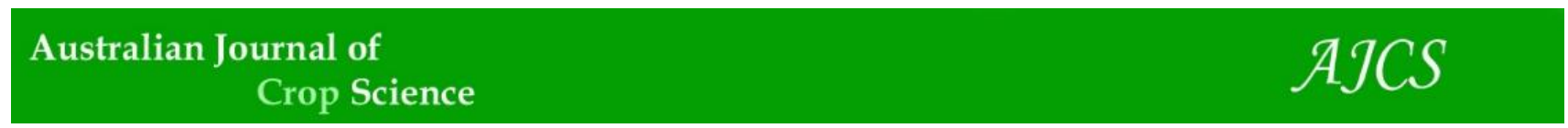

AJCS 15(06):851-858 (2021)

ISSN:1835-2707

doi: 10.21475/ajcs.21.15.06.p2986

\title{
Maize-soybean intercrop silage yield and quality with different nitrogen levels and plant population
}

\section{Vanderson Vieira Batista ${ }^{1 *}$, Paulo Fernando Adami ${ }^{2}$, Karine Fuschter Oligini ${ }^{1}$, Carlos Andre Barhy ${ }^{1}$, Laércio Ricardo Sartor ${ }^{1}$, Pedro Valério Dutra de Moraes²}

\author{
${ }^{1}$ Department of Agronomy, Technological University of Paraná, Via do Conhecimento, s/n - km 01 - Fraron, Pato \\ Branco - PR, Brazil, Zip Code 85503-390 \\ ${ }^{2}$ Department of Agronomy, Technological University of Paraná, Estrada para Boa Esperança, km 04 - Zona Rural, \\ Dois Vizinhos - PR, Brazil, Zip Code 85660-000
}

\section{*Corresponding author: vandersonvbatista@hotmail.com}

\begin{abstract}
This study hypothesizes that maize-soybean intercrop with lower maize plant population and nitrogen levels can allow better soybean development and yield, which may offset lower maize biomass and silage crude protein yield. Experiment was carried out in a randomized complete block design arranged in a $2 \times 5$ factorial scheme, with three replications. Treatments consisted of two different maize-soybean plant stand (40,000 and 60,000 plants ha-1) and five nitrogen fertilization levels $\left(0,50,100,150\right.$, and $\left.200 \mathrm{~kg} \mathrm{ha}^{-1}\right)$. As a result, soybean biomass yield increased at the lower maize plant stand, although, maize and total (maize + soybean) biomass yield were higher at the greater maize plant stand. Thus, individual maize plants and total dry matter yield increased as nitrogen levels were increased. However, there was no effect of the studied factors on the silage crude protein yield per area, indicating a great potential of soybean to offset biomass yield reduction trough silage quality improvement. Moreover, since there was no difference on total silage crude protein yield per hectare, it is suggested that the adoption of maize-soybean intercrop with lower maize plant stand ( 40 thousand maize plants $\mathrm{ha}^{-1}$ ) and with lower nitrogen values is a more environmentally friendly approach to increase farmland sustainability while decreasing environmental and productivity costs. Intermediate levels may be evaluated in future studies.
\end{abstract}

Keywords: Crude protein; Dry matter; Forage; Glycine max; Neutral detergent fiber; Plant arrangement; Production forage; Zea mays. Abbreviations: ANOVA_analysis of variance; SMP_stand of maize; SSP_stand soybean; DMM_dry matter of maize; DMS_dry matter of soybean; NPSP_number of pods per soybean plant; MDMY_ maize dry matter yield; SDMY_ soybean dry matter yield; TDMY_ total dry matter yield; MDMP_ maize dry matter per plant; SDMP_ soybean dry matter per plant; SDMP_ soybean dry matter percentage in silage; $\mathrm{pH}_{-}$hydrogen potential; NDF_ neutral detergent fiber; ADF_ acid detergent fiber; TDN_total digestible nutrients; $\mathrm{CP}_{-}$crude protein; $\mathrm{CPA}$ _ crude protein per area; PS_plant stand; NL_ nitrogen levels (NL); EU_ experimental units; UTFPR_Federal Technological University of Paraná.

\section{Introduction}

Maize and soybean intercrop have been widely studied in recent years. This system has greater efficiency in harnessing solar radiation and land use compared to conventional systems (crops grown alone) (Baghdadi et al., 2016). System adoption for grain purpose is still limited due to harvesting mechanical limitation, which is not a problem when crops are used for silage production. In this away, maize + soybean stands out as it provides silage with a higher crude protein content (Sánchez et al., 2010; Baghdadi et al., 2016; Stella et al., 2016; Batista et al., 2018; Batista et al., 2019a).

It is noteworthy that the quality of the roughage produced is as important as the quantity, especially for higher dairy productive cows. In this way, Stella et al. (2016) reported that maize silage crude protein content increased from $7.3 \%$ to 10.5 and $13.6 \%$ with the addition of 25 and $50 \%$ of soybean biomass, resulting in a crude protein increase of 44 and $86 \%$, respectively. According to the same researchers, increase the percentage of soybean biomass in the total ensiled amount (maize + soybean) is a challenge to be achieved in order to reach the expected benefits (increased crude protein content of silage). Thus, Batista et al. (2019a) studding maize + soybean intercrop with different arrangements reported soybean biomass amounts ranging from 7 to $13 \%$ in relation to the total maize biomass.

One strategy to enhance soybean development in the intercrop system would be to reduce maize population (plants per ha-1), although, there is a tradeoff between species and it is not known how much it would impact maize biomass yield and moreover the maize + soybean total yield per area since maize plant population plays a major role on the system. Thus, studies exploring the effect of plant population combinations on the intercropping production performance, in both crops, are fundamental for a better understanding of the maize/soybean intercropping use potential. Beyond plant population arrangement, its fertilization management may directly influence the competition between species since maize is highly responsive 
to nitrogen, increasing leaf area and biomass yield as nitrogen is increased (Ohland et al., 2005), which may increase suppression potential on soybean crop. On the other hand, soybean is a very efficient species to perform biological nitrogen fixation (Herridge et al., 2008), and it is essential to understand the effect of the nutrient on the intercropped species. It is worth noting lack of this information in the literature once the search for "nitrogen levels in maize/soybean intercropped" subject in scientific platforms (Scopus and Google Scholar) results in no data about the study area.

To address this, the study hypothesized that maize yield will be affected by lower plant density and nitrogen fertilization level, however, there will be a tread off with soybean yield, which will be higher in this cropping system, offsetting lower biomass production due to its higher protein content. By confirming this hypothesis, there will be a major chance into the silage productive system while at reducing mineral nitrogen demand, it reduces cost production and environmental problems, being a more sustainable option. In this way, the study investigates the effect of maize plant population and nitrogen fertilization levels on dry matter yield of maize-soybean intercrop for silage, besides investigating quality and digestibility silage parameters and assess the amount of crude protein produced at the different intercrop and nitrogen arrangements.

\section{Results and discussions}

\section{Maize and soybean final plant stand}

There was no interaction between maize plant stand and nitrogen levels for the intercrop plant stands, dry matter of both crops and number of pods per soybean plant. Thus, no statistical differences were observed in the variables to the nitrogen levels factor. However, it is noticed that the plant stand had a significant effect on the maize and soybean population and number of pods per soybean plant (Table 1 ). Higher number of pods per soybean plant observed in the treatment with lower maize plant stand, collaborates with the results observed in studies developed by Cruz et al. (2016), which report negative linear effect as plant stand increased. In the maize and soybeans intercrop, legumes are the most harmed by competition (Liu et al., 2017). The number of pods per plant is an important feature as it is directly related to the amount of grain, which can improve the nutritional quality of silage.

According to Ferreira et al. (2016), increasing soybean plant population reduces the number of pods per plant, regardless of the level of nitrogen fertilization added to the crop. Also, Batista et al. (2019a) evaluating different row arrangements in the maize-soybean intercrop, reported soybean pods increased as maize inter-row space increased, due to better light use efficiency.

It is important to highlight that the real population is very close to that stipulated for maize, with a reduction of only 1.67 and $3.89 \%$ between sowing density and final population

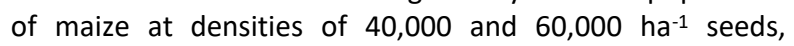
respectively. Its values show a greater difference for soybean, which showed a final population of 173,222 plants ha-1 (Table 1 ), or $19.16 \%$ below it was preconized.

There is no effect between nitrogen levels and plant stand, collaborating with monocrop studies conducted with maize (Batista et al., 2019b) and soybean (Ferreira et al., 2016). It is noteworthy that maize plant stand is the major yield component and its variation plays a major role on yield due to low maize phenotypic plasticity (Batista et al., 2019b). In this context, maize and soybean final plant stands observed reflects the treatments and its final stand were very close to the intended one.

Soybean plants produced $51 \%$ more pods at the treatment with lower maize stand in relation to the higher plant stand. Maize presented an average value of $36.41 \%$ of dry matter, showing a good relationship between grain stage and biomass dry matter. Soybean in the other hand, was still filling its grains and showed a lower dry matter content (27.38\%).

According to Cruz et al. (2008), maize silage should be harvested with dry matter content between 30 to $35 \%$, to associate good yield and microbial fermentation. Point out that maize has a similar dry matter percentage when grown in intercrop with soybean or monocrop (Batista et al., 2019a). Soybean for silage should be harvested just before the R7 stage (Leonel et al., 2008), when seeds are already filled and the lower leaves of the plant are starting to turn yellow, once at this point, soybean achieves maximum dry matter yield and is beginning to decrease moisture content. It is noteworthy to mention that at maize silage point (36.4\% dry matter) soybean was at R5.3 stage (beginning of grain fill), a fact that may have contributed to obtaining lower percentage of dry matter and biomass yield of soybean for silage. Short cycle cultivars (maturation group < 6.0) would fit better in intercrop.

Corn dry matter response to nitrogen levels is well documented in the literature (Santin et al., 2017) and is a consequence of the great demand from this nutrient, which exerts a potentiating effect on various features that influence crop yield (Ohland et al., 2005). Results (Table 2) also collaborate with Pereira et al. (2018), which evaluated maize stands of 49,500; 66,000; and 82,500 plants ha-1, and concluded that increasing plant stands provides a significant increase in silage production.

\section{Intercrop Silage biomass yield}

There was a significant effect of both, plant stand and nitrogen level to the silage biomass yield. Regarding to plant stand, higher maize population (57,666 plants ha-1) produced more biomass $\left(3,690 \mathrm{~kg} \mathrm{DM} \mathrm{ha}^{-1}\right)$ than the treatment with lower maize plant stand $\left(39,333\right.$ plants $\left.h^{-1}\right)$. In the other hand, soybean biomass increased from 2,142 to $2,762 \mathrm{~kg} \mathrm{DM}$ $\mathrm{ha}^{-1}$, although, this biomass yield difference (620 kg DM ha-1) is not able to offset lower maize biomass yield, resulting in a lower total yield.

Regarding to the nitrogen levels, maize and total biomass also increased as nitrogen levels were increased, fitting a linear curve (Figure 1A). Regarding soybean dry matter yield, there was significant interaction between the factors studied (Table 2). Soybean results were best represented by the quadratic model, which best represents the behavior of nitrogen levels in both sowing densities. At sowing density of 60,000 seeds $\mathrm{ha}^{-1}$, the polynomial regression had a maximum yield point of soybean dry matter $\left(2,264.75 \mathrm{~kg} \mathrm{ha}^{-1}\right)$ at the level of $63 \mathrm{~kg} \mathrm{ha}$ ${ }^{1}$ of $\mathrm{N}$ while at sowing density of 40,000 plants ha ${ }^{-1}$ had a minimum yield point $\left(2,529.15 \mathrm{~kg} \mathrm{ha}^{-1}\right)$ at $57 \mathrm{~kg} \mathrm{ha}^{-1}$ of $\mathrm{N}$ input (Figure 1B). It was also noticed a soybean dry matter yield increased at the higher nitrogen levels $(100,150$, and $200 \mathrm{~kg}$ $\mathrm{ha}^{-1} \mathrm{~N}$ ) at the treatment with 40 thousand plants ha-1, probably explained by lower competition (Figure 1B).

There was no interaction between the evaluated factors for total dry matter yield. However, higher maize sowing density exhibits a yield of $3,071 \mathrm{~kg} \mathrm{ha}^{-1}$ superior when compared to the lower maize sowing density (Table 2). Also, total dry matter yield increases as nitrogen level increase (13.369x + 19.085) (Figure 1A). 
In relation to maize dry matter per plant, lower stand resulted in heavier ( $409 \mathrm{~g}$ ) plants than higher stand (343 g), differing in more than $66 \mathrm{~g}$ per plant (Table 2 ). Concerning to the nitrogen levels, it is noticed a linear effect $(0.2261 x+345.02)$ on maize dry matter yield per plant (Table 2) (Figure $1 \mathrm{C}$ ). In the other hand, soybean dry matter per plant showed a similar tendency among nitrogen levels, although it differed between sowing density, showing lower weights ( $8.2 \mathrm{~g}$ or $39 \%$ less) at the higher maize plant stand treatment.

Higher total dry matter yield is directly related to maize dry matter yield, which increases as plant stand and nitrogen levels increased. Regarding to nitrogen levels, it is possible to infer that high nitrogen levels ( $>100 \mathrm{~kg} \mathrm{~N} \mathrm{ha}^{-1}$ ) reduced interspecific plant competition and allowed soybean to grown more even being shaded by maize plants at the lower plant stand. Higher amounts of available nitrogen improved soybean dry matter yield at the lower maize plant stand, thus, this result was not noticed to the higher plant stand, where the greater number of maize plants resulted in greater competition, reducing soybean biomass as nitrogen levels were increased. According to Chen et al. (2019), maizesoybean intercrop increased $\mathrm{N}$ use efficiency by increasing $\mathrm{N}$ utilization efficiency (reduce $\mathrm{N}$ loss), rather than $\mathrm{N}$ uptake efficiency (Chen et al., 2019).

At the maize plant stand of 57,666 plants ha-1, soybean dry matter yield decreased, even with higher nitrogen levels. This could be related to the higher dry matter yield of maize, which suppressed soybean development at higher nitrogen levels. Beyond nutrient competition, shading effect may be the may cause of lower soybean biomass production.

Similar results were reported by Liu et al. (2017), which showed that the reduction of photosynthetic radiation intercepted by soybean in the maize-soybean intercropping reduced soybean plant development and crop biomass accumulation (Liu et al., 2017). Thus, an increase in plant stand of maize causes a higher competition with soybean for light, water, and nutrients, consequently resulting in reduced crop biomass yield.

Another important data is the soybean percentage in the silage. There was an interaction for this variable in a way that at lower maize stand, nitrogen levels did not increase the percentage of soybean in the silage, showing an average value of $14.65 \%$ (Figure 1D). However, at higher maize stand, soybean biomass percentage in silage decrease as nitrogen is increased $(-0,0147 x+11,336)$ (Figure 1D). Also, soybean percentage in silage was higher in the sowing density of 39,333 plants ha-1, except for using $50 \mathrm{~kg} \mathrm{ha}^{-1}$ of $\mathrm{N}$, which presents statistically similar values, regardless of the sowing density used (Figure 1D).

The combination of these variables (dry matter yield of maize and soybean) provided the reported interaction for soybean percentage in silage. The percentage of legume biomass to be ensiled in the total amount of the silage is an important factor, since it can influence the silage fermentation and increase the crude protein content of silage (Stella et al., 2016). In addition to the difference in biomass yield, the different ability of plants to express the potential of pods and grains may reduce differences between treatments, especially for the variable crude protein yield per area.

\section{Intercrop Silage quality}

As regards to the silage traits $(\mathrm{pH}$, ashes, neutral detergent fiber, acid detergent fiber, total digestible nutrients, and crude protein), only ashes and crude protein content showed an interaction between the evaluated factors (Table 3). Silage $\mathrm{pH}$ was influenced by plant sowing density, being $5 \%$ higher when using 40,000 seeds ha-1. This is possibly related to the higher percentage of soybean biomass into the silage. According to Stella et al. (2016) silage $\mathrm{pH}$ increases as the percentage of soybean biomass increases into the silage, although, the authors report that $\mathrm{pH}$ was maintained at accepted levels up to the inclusion level of $50 \%$ of soybean. According to the authors, this fact occurs because legumes have higher buffering capacity, preventing the $\mathrm{pH}$ from rapidly decreasing. Thus. the evaluated nitrogen levels had no significant effect on the silage $\mathrm{pH}$.

Ashes content were similar among nitrogen levels at the lower maize plant stand (Figure $1 \mathrm{E}$ ) with a mean of $4.17 \%$. At the higher maize plant stands a quadratic behavior of the data was noticed, with the highest value of ash (4.31\%) obtained with the use of $72.15 \mathrm{~kg} \mathrm{ha}^{-1}$ of $\mathrm{N}$. In relation to the silage crude protein (Figure $1 \mathrm{~F}$ ), it is noticed a quadratic behavior at the lower maize stand in relation to the nitrogen levels, with higher crude protein value at higher nitrogen rates. At the higher maize plant stand, silage crude protein content showed a similar tendency with a mean of $8.4 \%$ (Figure $1 \mathrm{~F}$ ). The observed changes in crude protein content are also reported by other studies involving maize-soybean intercrop for silage (Sánchez et al., 2010; Stella et al., 2016; Batista et al., 2018; Batista et al., 2019b). It is noticed that there is a tendency of increase of this silage trait, as soybean biomass proportion on silage biomass is increased.

For the variables related to silage digestibility, there was no interaction between the factors, neither statistical difference when analyzing the main effect, which collaborate with other scientific researches (Sánchez et al., 2010; Batista et al., 2018; Batista et al., 2019a). Mean averages were 45, 23 and 71\% respectively for neutral and acid detergent fiber and total digestible nutrient.

Also, no statistically significant effect on crude protein yield per area was reported, with an average of $1,802.17 \mathrm{~kg} \mathrm{ha}^{-1}$ (Table 3 ). These results demonstrate that the addition of soybean biomass into maize biomass to be ensiled has a great potential to improve the silage quality, increasing the ashes and crude protein content. Also, associated with this fact, the similar digestibility among the treatments stands out, favoring the association of the species to the ensiling process. However, it is important to highlight that soybean higher dry matter yield at lower maize plant stand did not offset the lower maize dry matter yield, being the total dry matter yield $3,071 \mathrm{~kg} \mathrm{DM} \mathrm{ha}^{-1}$ lower at this treatment. Although, it is also reported that at low maize plant stand, soybean presented higher dry matter values, higher number of pods per plant, and higher crude protein content, and that these facts combined provided similar values of protein yield per area. Knowing that the protein is the most expensive component for animal feed and, considering the nutritional quality of silage, it should be noted that the farmer can cultivate his maize-soybean intercropping for silage with the lower maize plant stand (40 thousand plant ha-1) without or adding lower levels of nitrogen into the system, saving agricultural inputs and reducing cost production. New researches with intermediate maize populations or different inter-row arrangements than those studied in this project may be a strategy in the way of seeking greater success in the maizesoybean intercrop.

\section{Materials and methods}

\section{Experimental site}

Study was carried out at Agricultural Research Station and the Bromatological Analysis Laboratory of the Federal Technolo- 
Table 1. Stand of maize (SMP) and soybean (SSP) plants ha-1 ${ }^{-1}$ dry matter of maize (DMM) (\%), soybean (DMS) (\%), and number of pods per soybean plant (NPSP) in the maize-soybean intercrop related to the plant stand and nitrogen levels, UTFPR, Dois Vizinhos Brazil, 2019.

\begin{tabular}{|c|c|c|c|c|c|}
\hline Treatments & SMP & SSP & DMM & DMS & NPSP \\
\hline \multicolumn{6}{|c|}{ Plant stand (PS) (plants ha-1) } \\
\hline 40,000 & $39,333.33 \mathrm{~b}$ & $133,888.89 \mathrm{~b}$ & 36.48 & 27.39 & $21.67 \mathrm{a}$ \\
\hline 60,000 & $57,666.67 a$ & $173,222.22 \mathrm{a}$ & 36.34 & 27.38 & $14.31 \mathrm{~b}$ \\
\hline \multicolumn{6}{|c|}{ Nitrogen levels (NL) (kg ha-1) } \\
\hline 0 & $48,055.56$ & $153,055.56$ & 36.86 & 27.32 & 16.37 \\
\hline 50 & $48,611.11$ & $157,222.22$ & 36.48 & 26.69 & 16.50 \\
\hline 100 & $48,888.89$ & $155,000.00$ & 36.42 & 27.70 & 19.53 \\
\hline 150 & $48,333.33$ & $152,777.78$ & 35.28 & 27.22 & 19.80 \\
\hline \multirow[t]{2}{*}{200} & $48,611.11$ & $149,722.22$ & 37.00 & 28.05 & 17.73 \\
\hline & & $P$-value & & & \\
\hline OS & 0.0000 & 0.0000 & 0.7573 & 0.9961 & 0.0000 \\
\hline $\mathrm{NL}$ & 0.9161 & 0.8478 & 0.1665 & 0.2505 & 0.3214 \\
\hline PS*NL & 0.8941 & 0.8014 & 0.1637 & 0.0706 & 0.9734 \\
\hline Mean & $48,500.00$ & $153,555.56$ & 36.41 & 27.38 & 17.99 \\
\hline
\end{tabular}

$(p<0.05)$ - There is statistical difference among treatments. Means followed by different letters in the columns differ by the $F$ test in $5 \%$ of probability.

Table 2. Maize (MDMY), soybean (SDMY) and total (TDMY) dry matter yield (kg ha-1), maize (MDMP) and soybean (SDMP) dry matter per plant (g), and soybean dry matter percentage in silage (SDMP) (\%) at the Maize-soybean intercrop in relation to plant stand and nitrogen levels, UTFPR, Dois Vizinhos - Brazil, 2019.

\begin{tabular}{|c|c|c|c|c|c|c|}
\hline Treatments & MDMY & SDMY & TDMY & MDMP & SDMP & SDMP \\
\hline \multicolumn{7}{|c|}{ Plant stand (SD) (plants ha-1) } \\
\hline 40.000 & $16,124.50 \mathrm{~b}$ & $2,761.92$ & $18,886.42 b$ & $409.71 \mathrm{a}$ & $20.64 \mathrm{a}$ & $14.65 \mathrm{a}$ \\
\hline 60.000 & $19,814.71$ a & $2,142.38$ & $21,957.09$ a & $343.55 \mathrm{~b}$ & $12.41 \mathrm{~b}$ & $9.86 \mathrm{~b}$ \\
\hline \multicolumn{7}{|c|}{ Nitrogen level (NL) (kg ha-1) } \\
\hline 0 & $16,954.77$ & $2,406.03$ & $19,360.81$ & 360.09 & 16.23 & 12.60 \\
\hline 50 & $17,509.04$ & $2,386.44$ & $19,895.47$ & 369.35 & 15.65 & 12.05 \\
\hline 100 & $17,688.19$ & $2,491.40$ & $20,179.42$ & 367.16 & 16.65 & 12.58 \\
\hline 150 & $17,664.79$ & $2,379.62$ & $20,044.41$ & 370.51 & 16.00 & 12.11 \\
\hline 200 & $20,031.40$ & $2,597.26$ & $22,628.67$ & 416.04 & 18.08 & 11.94 \\
\hline \multicolumn{7}{|l|}{$P$-value } \\
\hline PS & 0.0000 & 0.0000 & 0.0001 & 0.0000 & 0.0000 & 0.0000 \\
\hline $\mathrm{NL}$ & 0.0400 & 0.6068 & 0.0396 & 0.0499 & 0.2820 & 0.8752 \\
\hline PS*NL & 0.3498 & 0.0202 & 0.6999 & 0.6425 & 0.0676 & 0.0160 \\
\hline Mean & $17,969.60$ & $2,452.15$ & $20,421.76$ & 376.63 & 16.52 & 12.26 \\
\hline
\end{tabular}

$(p<0.05)$ - there is statistical difference among treatments. Means followed by different letters in the columns differ by the $F$ test in $5 \%$ of probability.

Table 3. Hydrogen potential (pH), ashes (\%), neutral detergent fiber (NDF) (\%), acid detergent fiber (ADF) (\%), total digestible nutrients (TDN) (\%), crude protein (CP) (\%), and crude protein per area (CPA) $\left(\mathrm{kg} \mathrm{ha}^{-1}\right)$ at the maize-soybean intercrop in relation to plant stand and nitrogen levels, UTFPR, Dois Vizinhos - Brazil, 2019

\begin{tabular}{|c|c|c|c|c|c|c|c|}
\hline Trataments & $\mathrm{pH}$ & Ashes & NDF & ADF & TDN & $\mathrm{CP}$ & CPA \\
\hline \multicolumn{8}{|c|}{ Plant stand (PS) (plants ha $a^{-1}$ ) } \\
\hline 40 & $4.45 \mathrm{a}$ & 4.18 & 45.30 & 22.75 & 71.91 & 9.33 & $1,762.35$ \\
\hline 60 & $4.23 \mathrm{~b}$ & 4.02 & 46.52 & 23.87 & 71.13 & 8.42 & $1,841.99$ \\
\hline \multicolumn{8}{|c|}{ Nitrogen levels (NL) $\left(\mathrm{kg} \mathrm{ha}^{-1}\right)$} \\
\hline 0 & 4.33 & 4.27 & 47.53 & 23.43 & 71.44 & 8.67 & $1,674.65$ \\
\hline 50 & 4.35 & 4.17 & 46.22 & 24.11 & 70.96 & 8.71 & $1,730.70$ \\
\hline 100 & 4.36 & 4.26 & 45.76 & 22.91 & 71.81 & 8.94 & $1,808.85$ \\
\hline 150 & 4.32 & 3.95 & 45.99 & 24.10 & 70.97 & 9.05 & $1,789.18$ \\
\hline 200 & 4.32 & 3.81 & 44.05 & 22.01 & 72.43 & 9.03 & $2,007.46$ \\
\hline \multicolumn{8}{|l|}{$P$-value } \\
\hline PS & 0.0000 & 0.1671 & 0.3413 & 0.2643 & 0.2643 & 0.0067 & 0.2489 \\
\hline $\mathrm{NL}$ & 0.9467 & 0.0409 & 0.5396 & 0.6218 & 0.6218 & 0.8805 & 0.0541 \\
\hline PS*NL & 0.7888 & 0.0181 & 0.1096 & 0.1627 & 0.1627 & 0.0060 & 0.0717 \\
\hline Mean & 4.34 & 4.09 & 45.91 & 23.31 & 71.52 & 8.88 & $1,802.17$ \\
\hline
\end{tabular}

$(p<0.05)$ - there is statistical difference among treatments. Means followed by different letters in the columns differ by the $F$ test in $5 \%$ of probability. 

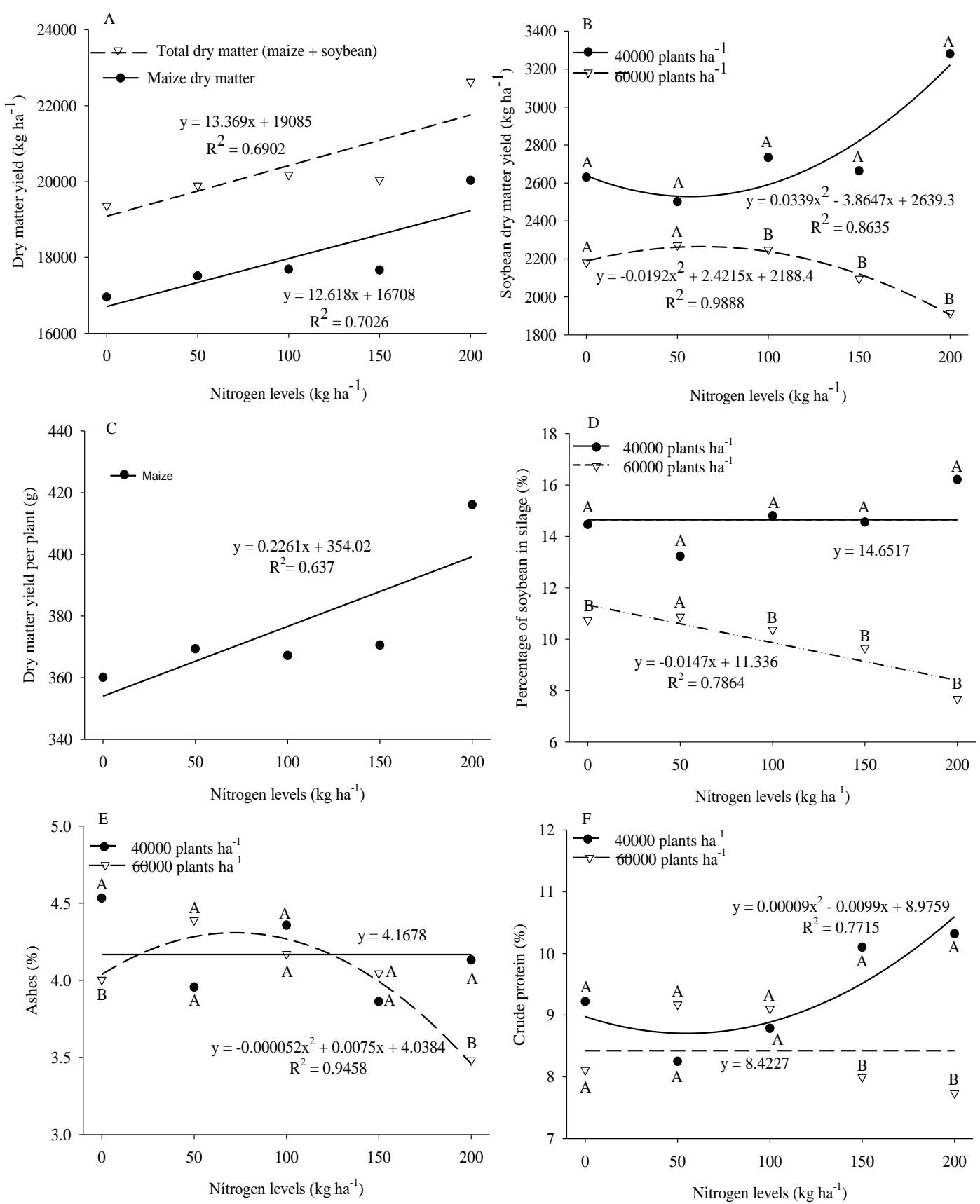

Fig 1. Maize and total (maize-soybean) dry matter yield (A), soybean dry matter yield (B), maize dry matter per plant (C), soybean percentage of dry matter in silage (D), ashes (E), and crude protein content (F) of the Maize-soybean intercrop in relation to plant stand and nitrogen levels, UTFPR, Dois Vizinhos - Brazil, 2019.

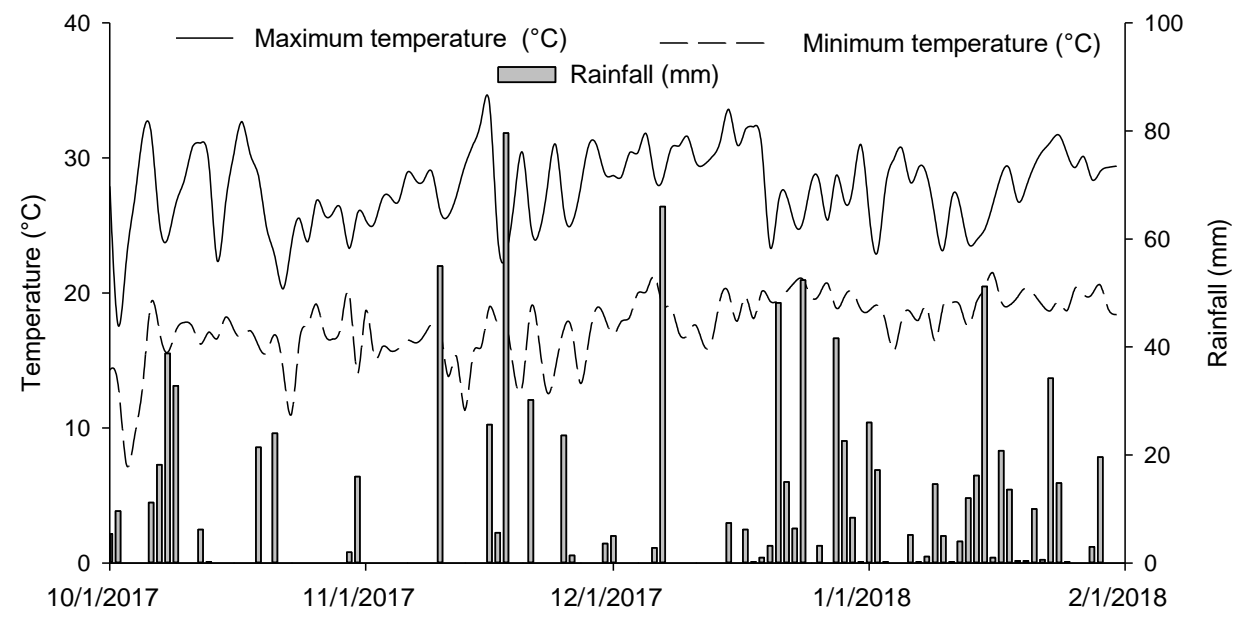

Fig 2. Rainfall, Maximum and minimum temperature recorded along the experiment field phase, UTFPR, Dois Vizinhos - Brazil, 2019. 


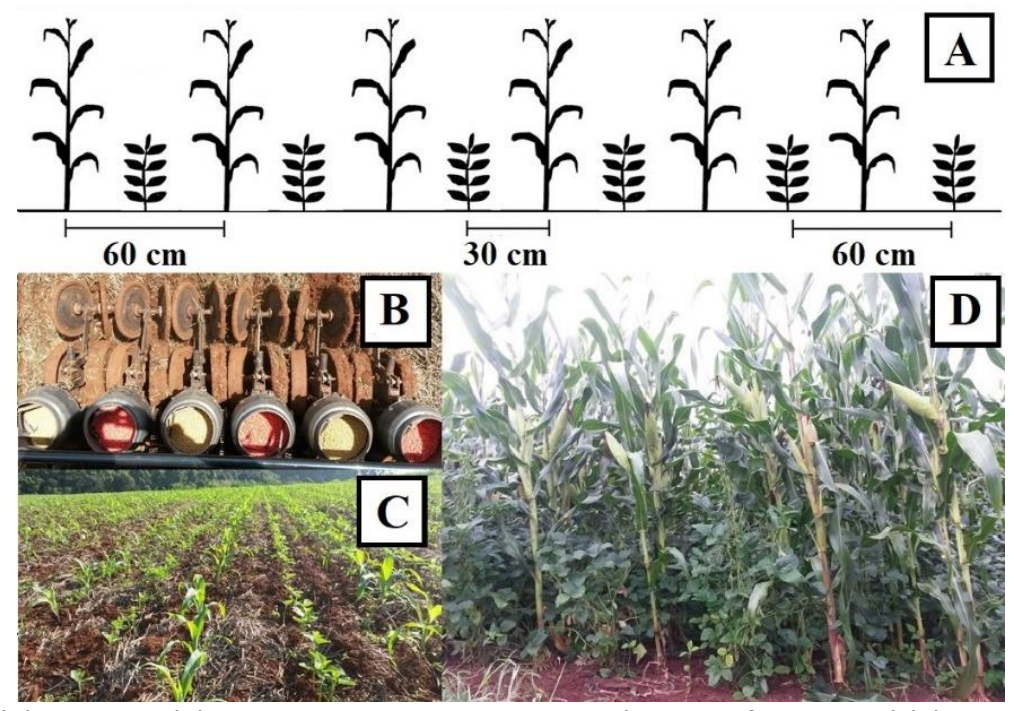

Fig 3. Row arrangements (A) at sowing (B), maize at V4 phenological stage (nitrogen fertilization) (C), and maize at silage point (D) in the maize-soybean intercrop with different plant density and nitrogen levels, UTFPR, Dois Vizinhos - Brazil, 2019.

gical University of Paraná (UTFPR), campus of Dois VizinhosParaná, Brazil.

The climate is classified as Cfa (Alvares et al., 2013), with an average rainfall of approximately $2000 \mathrm{~mm}$ per year (Inmet, 2019), which are distributed along the year. Data for minimum and maximum temperature and rainfall, registered during the study, are shown in Figure 2.

The experimental site has an average altitude of $530 \mathrm{~m}$ above sea level and soil is classified as Clayey Oxisol (Bhering et al., 2009). Soil chemical properties (0.0-0.1 m layer) were: organic matter (OM) $44.23 \mathrm{~g} \mathrm{dm}^{-3}$, phosphorus (P) $36.65 \mathrm{mg} \mathrm{dm}^{-3}$, potassium (K) $0.28 \mathrm{cmol}_{\mathrm{c}} \mathrm{dm}^{-3}$, magnesium $(\mathrm{Mg}) 1.50 \mathrm{cmol}_{\mathrm{c}}$

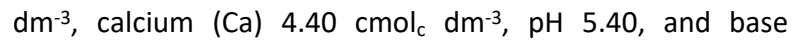
saturation $67.69 \%$. It is noteworthy that the area has a history of good fertility management, with a no-tillage system consolidated for more than 10 years, being cultivated in the summer with soybean, maize or beans; and oats (cover crop) or wheat during the winter.

\section{Treatments and Experimental design}

Treatments consisted of different maize plant densities $(40,000$ and 60,000 seeds ha-1) and different levels of nitrogen fertilization $\left(0,50,100,150\right.$, and $\left.200 \mathrm{~kg} \mathrm{ha}^{-1}\right)$ The study was laid out in a randomized complete block design arranged in a $2 \times 5$ factorial scheme with three replications. Each experimental plot consisted of $3.6 \mathrm{~m}$ wide and $10 \mathrm{~m}$ long.

\section{Maize and soybean characterization}

Maize hybrid 2B533 which is classified as an early triple hybrid and is recommended for both grain and silage production was used (Forssed, 2019). As for soybean crop, the cultivar TMG7062-IPRO Intacta RR2 PROTM was used, which is genetically modified allowing the plant to protect itself against the main caterpillar species, presenting rust tolerance (Phakopsora pachyrhizi) and maturity group 6.2 (TMG, 2018).

\section{Experimental evaluations}

Evaluations were performed in the experimental units (EU), which consisted of the central rows of each crop (maize and soybean), in each experimental unit, with $8 \mathrm{~m}$ long $\left(9.6 \mathrm{~m}^{2}\right)$. Intercrop species were sowed with a $60 \mathrm{~cm}$ row spacing for maize/maize, with a soybean row between maize rows, resulting in $30 \mathrm{~cm}$ between rows for maize/soybean (Figure $3 A$, Figure 3B).
Glyphosate was applied at the prior crop (Avena Strigosa) at a dose of $1,080 \mathrm{~g}$ a.i. per hectare 30 days before the intercrop establishment. Maize-soybean intercrop was sown simultaneously, under no-tillage system, with the aid of a hydraulic seed-drill on October $2^{\text {nd }}$. Crops establishment and seeder adjustments were set up to maize crop, being the soybean plant stand a result of it. Soybean and maize seed discs with 100 and 28 holes respectively were used. In this way, to each maize seed sowed, there was 3.57 soybean seeds sowed, turning out in a good relationship. In may be translated to 142,857 and 214,288 soybean seeds ha-1, at the treatments with 40,000 and 60,000 maize seeds ha-1 seeds, respectively. Along with the sowing, base fertilization was performed for both species, adding $400 \mathrm{~kg} \mathrm{ha}^{-1}$ of chemical fertilizer 5-20-10 (N- $\left.\mathrm{P}_{2} \mathrm{O}_{2}-\mathrm{K}_{2} \mathrm{O}\right)$.

Insecticide imidacloprid + beta-cyfluthrin at the dose of $1 \mathrm{~L} \mathrm{ha-}$ ${ }^{1}$ was applied, shortly after maize emergence to control stink bug (Dichelops melacanthus). Weed control was achieved by applying glyphosate $(1,080 \mathrm{~g}$ a.i. ha-1) on maize at $\mathrm{V} 3$ stage. When maize was at V4 phenological stage (Figure 3C) nitrogen levels $(\mathrm{N})$ were topdressing applied with urea $(45 \%$ $\mathrm{N})$. Fungicide application was done at maize R2 stage with a systemic ready mixture product containing strobilurin + pyrazole carboxamide at a commercial dose of $300 \mathrm{~g} \mathrm{ha}^{-1}$. Along with the fungicide, vegetable oil was added $\left(0.5 \mathrm{~L} \mathrm{ha}^{-1}\right)$. Defensives were applied by a self-propelled sprayer with a spray volume of $160 \mathrm{~L} \mathrm{ha}^{-1}$ with.

Maize ensiling (at $3 / 4$ milk line stage) occurred on February $1^{\text {st }}$ of 2018 (122 days after sowing) (Figure 3D). Maize and soybean plants population were determined at the silage point by counting the number of plants in each EU and extrapolating to hectare (plants ha-1). Also, soybean number of pods per plant was assessed in ten randomized plants per EU. Plants from EU were harvested at $25 \mathrm{~cm}$ above soil surface. These samples were weighed (per crop) to estimate green biomass accumulation $\left(\mathrm{kg} \mathrm{ha}^{-1}\right)$. Then, samples of both crops were ground on a forage harvester with an average particle size of $1 \mathrm{~cm}$. A sample of $300 \mathrm{~g}$ of maize and soybean silage per EU were placed in a paper bag and over-dried with forced air at $65^{\circ} \mathrm{C}$ until constant mass, then weighed again to determine the dry matter percentage for both crops. Dry matter percentages of each crop, in each EU, were related to the respective green biomass yield values to obtain the crop dry matter yield $\left(\mathrm{kg} \mathrm{ha}^{-1}\right)$. Also, by adding the values of maize 
dry matter yield and soybean yield in the respective EU, the total dry matter yield (silage) $\left(\mathrm{kg} \mathrm{ha}^{-1}\right)$ was determined.

Dry matter yield per plant (g) was also determined by dividing the total dry matter yield by its plant population of the respective crop. The percentage of soybean dry matter in silage (\%) was calculated as well, relating the values of total dry matter and soybean dry matter. Maize and soybean (green biomass) samples that had been collected to determine biomass yield were grouped and mixed into the corresponding EU, to obtain homogeneous biomass. Samples of $3 \mathrm{~kg}$ of biomass (keeping the real proportion between maize and soybean) were packed into laboratory silos made of PVC pipes ( $100 \mathrm{~mm}$ in diameter and $600 \mathrm{~mm}$ in length). The silos were sealed with PVC caps and stores for 60 days in the shadow for silage fermentation process.

After this period, the silos were opened and the hydrogen potential $(\mathrm{pH})$ of the silage determinated (Silva and Queiroz, 2002). From the silo silage, a sample was collected ( $300 \mathrm{~g}$ ) and placed in paper bags, oven-dried with forced air circulation at $65{ }^{\circ} \mathrm{C}$ until constant mass. Dried samples were ground in a 'Willey' type mill with a $1 \mathrm{~mm}$ mesh sieve, and the samples taken to the Bromatological Analysis Laboratory. Silage crude protein analysis (\%) was performed by quantifying the $\mathrm{N}$ present in the samples according to the methodology described by Tedesco et al. (1995), ashes (\%) (Silva and Queiroz, 2002), neutral detergent fiber (NDF) (\%), and acid detergent fiber (ADF) (\%) were determined according to the methodology described in the Ankon manual (Ankom, 2009). Also, total digestible nutrients from silage were estimated by multiplying acid detergent fiber by 0.7 and subtracting of 87.84 (Pionner, 2019). In addition, by multiplying the silage crude protein by the total dry mass yield, crude protein yield per area $\left(\mathrm{kg} \mathrm{ha}^{-1}\right)$ was estimated.

\section{Statistical analysis}

Data were subjected to analysis of variance (ANOVA) at 5\% probability and verifying the significant effect among treatments, regression analysis was applied for nitrogen levels and $\mathrm{F}$ test for plant stand. For the analysis of the data, Sisvar 5.6 software was used (Ferreira, 2008).

\section{Conclusions}

Soybean intercrop with lower maize stand yielded higher dry matter biomass with a greater number of pods per plant and higher ashes and crude protein content.

Silage digestibility is not influenced by the evaluated treatments.

Maize and total silage dry matter yield increased as nitrogen level increased in the maize-soybean intercropping system without affect although the crude protein yield per area, which was similar among treatments.

\section{Acknowledgments}

The authors are grateful to AGRISUS (Foundation for Sustainable Agriculture) for providing money resource for the project number 2787/19 and to CAPES (Coordination for the Improvement of Higher Education Personnel) for providing a scholarship for the student and UTFPR-DV.

\section{References}

Alvares CA, Stape JL, Sentelhas PC, de Moraes G, Leonardo J, Sparovek G (2013) Köppen's climate classification map for Brazil. Meteorologische Zeitschrift. 22(6):711-28.
Ankom (2009) Technology method 2: rapid determination of oil/fat utilizing high temperature solvent extraction. Macedon.

Baghdadi A, Halim RA, Othman R, Yusof MM, Atashgahi ARM (2016) Productivity, relative yield and plant growth of forage corn intercropped with soybean under different crop combination ratio. Legume Research-An International Journal. 39(4):558-64.

Batista VV, Adami PF, Moraes PVD, Oligini KF, Giacomel CL, Link L (2019a) Row arrangements of maize and soybean intercrop on silage quality and grain yield. Journal of Agricultural Science. 11(2): 286-300.

Batista VV, Adami PF, Sartor LR, Silveira MF, Soares AB, Oligini $\mathrm{KF}$, Kwiecinski $\mathrm{D}$, Ferreira $\mathrm{ML}$, Camana $\mathrm{D}$, Giacomel $\mathrm{CL}$, Fonseca AC (2018) Forage yield and silage quality of intercropped maize+soybean with different relative maturity cycle. Journal of Agricultural Science. 10(12): 24961.

Batista VV, Giaretta R, Link L, Giacomel CL, Adami PF (2019b) Densidades de plantas e níveis de nitrogênio no desempenho de híbridos de milho em safrinha. Revista Nativa. 7(2):117-25

Bhering SB, dos Santos HG, Bognola IA, Curcio GR, Carvalho Júnior W, Chagas CS, Manzatto CV, Áglio ML, Silva JS (2009) O solo e a produção de bioenergia: perspectivas e desafios. In: Congresso brasileiro de ciência do solo, Fortaleza, 2009. Chen $\mathrm{P}$, Song $\mathrm{C}$, Liu XM, Zhou L, Yang H, Zhang X, Zhou Y, Du Q, Pang T, Fu ZD, Wang XC, Liu WG, Yang F, Shu K, Du J, Liu $J$, Yang $W$, Yong $T$ (2019) Yield advantage and nitrogen fate in an additive maize-soybean relay intercropping system. Science of the Total Environment. 657:987-99.

Cruz JCC, Albemaz WMA, Ferreira JJ (2008) Qualidade da silagem de milho em função do teor de matéria seca na ocasião da colheita. Embrapa Milho e Sorgo-Circular Técnica. 1518: 42-69.

Cruz SCS, Junior DGS, dos Santos DMA, Lunezzo LO, Machado CG (2016) Cultivo de soja sob diferentes densidades de semeadura e arranjos espaciais. Revista de Agricultura Neotropical. 3(1):1-6.

Ferreira AS, Balbinot Junior AA, Werner F, Zucareli C, Franchini JC, Debiasi H (2016) Plant density and mineral nitrogen fertilization influencing yield, yield components and concentration of oil and protein in soybean grains. Bragantia. 75(3):362-70.

Ferreira DF (2008) Sisvar: Um programa para análises e ensino de estatística. Revista Symposium. 6(2):36-41.

Forssed (2019) Híbrido Precoce Para Médio / Alto Investimento. Available in: https://www.forseedsementes.com.br/portfolio/produtos /2b533pw-2/. Access in: October, 2019.

Herridge D, Peoples M, Boddey RM (2008) Global inputs of biological nitrogen fixation in agricultural systems. Plant and Soil. 311(1):1-18.

Instituto Nacional De Meteorologia - Inmet (2019) Estações e Dados. Available in: http://www.inmet.gov.br/portal/. Access in: August, 2019.

Liu X, Rahman T, Yang F, Song C, Yong T, Liu J, Zhang C, Yang W (2017) Par interception and utilization in different maize and soybean intercropping patterns. Plos One. 12(1):1-17.

Leonel FP, Pereira JC, Costa MG, Júnior PDM, Lara LA, Sousa DP, Silva CJ (2008) Consórcio capim-braquiária e soja, produtividade das culturas e características qualitativas das silagens. Revista Brasileira de Zootecnia. 37(11):2031-40. 
Ohland RAA, Souza LCFD, Hernani LC, Marchetti ME, Gonçalves MC (2005) Culturas de cobertura do solo e adubação nitrogenada no milho em plantio direto. Ciência e Agrotecnologia. 29(3):538-44.

Pereira LB, Machado DS, Alves Filho DC, Brondani IL, da Silva VS, Argenta FM, Moura AF, Borchate D (2018) Características agronômicas da planta e produtividade da silagem e grãos de milho submetido a diferentes arranjos populacionais. Magistra. 29(1):18-27.

Pionner (2019) Análise Bromatológica. Available in: http://www.pioneersementes.com.br/milho/silagem/anali se-bromatologica. Access in: January, 2019.

Sánchez DGR, Espinosa S, Palomo G, Serrato C, Cueto W, Gaytán, M (2010) Forage yield and quality of intercropped corn and soybean in narrow strips. Spanish Journal of Agricultural Research. 8(3):713-21.
Santin AA, Rosa SJ, Schmitz L, Borsoi FT, Nesi CN (2017) Efeito da adubação nitrogenada e do espaçamento entre linhas sobre a silagem de milho. Unoesc \& Ciência. 8(1):45-52.

Stella LA, Peripolli V, Prates ÊR, Barcellos JOJ (2016) Composição química das silagens de milho e sorgo com inclusão de planta inteira de soja. Boletim de Indústria Animal. 73(1):73-79.

Sila DJ, Queiroz AC (2002) Análises de alimentos. In: Métodos químicos e biológicos, 3rd edn. Minas Gerais, Viçosa. 2.

Tedesco MJ, Tedesco M, Gianello C, Biassi C, Bohnen H, Volkweiss S (1995) Análises de solo, plantas e outros materiais, 2nd edn. Porto Alegre, Rio Grande do Sul. 5.

Tmg 7062 Ipro. Available in: http://www.tmg.agr.br/cultivar/tmg-7062-ipro. Access in: January, 2018. 